УДК 796.41.015.31:159.9

DOI https://doi.org/10.26661/2663-5925-2021-3-12

\title{
ОСОБЛИВОСТІ ПСИХОЛОГІЧНОЇ ПІДГОТОВКИ В СПОРТИВНІЙ ГІМНАСТИЦІ
}

\author{
Колеснік I. B. \\ викладач кафедри спортивних видів гімнастики \\ Національний університет фізичного виховання і спорту Украйни \\ вул. Фізкультури, 1, Київ, Україна \\ orcid.org/0000-0002-0653-907X \\ irynarosev@ukr.net
}

Ключові слова: види підготовки, психологія спорту, навчальнотренувальний процес, гімнасти, змагання.
У статті представлено проблематику психологічної підготовки в навчально-тренувальному процесі гімнастів. Також викладено результати теоретичного дослідження щодо вивчення особливостей психологічної підготовки в спорті.

Доведено, що недостатня психологічна підготовка може призводити до нестабільного виступу на змаганнях та невдалого підходу за поганого психологічного налаштування спортсмена. Слід зазначити, що в спортивній гімнастиці починають займатися юні гімнасти ще 3 несформованим характером, не маючи стійкості морально-вольових якостей.

Отже, недостатня увага психологічної підготовки спостерігається ще в шкільному віці, коли дитина приходить займатися спортом, а тренери вважають, що найголовніше - це розвиток фізичних якостей (швидкості, витривалості, сили, гнучкості), а використання спеціальних прийомів щодо розвитку впевненості у своїх силах на тренуваннях та перед змаганнями може відійти на другий план. Також слід зазначити, що психологічна підготовка найчастіше використовується для означення широкого кола дій тренерів, спортсменів і менеджерів, що спрямовані на формування і розвиток психічних процесів та якостей особистості спортсменів і є необхідними для успішної тренувальної діяльності та виступів на змаганнях. Зазначимо також, що напрям психологічної підготовки передбачає розвиток мотивів, волі, почуттів, здібностей, характеру, темпераменту та інших психологічних якостей, а також формує спеціалізоване сприймання і динаміку передстартових станів, психічної стійкості, надійності спортсмена. У статті особливу увагу приділено вивченню сутності психологічної підготовки спортсменів, розглянуто їі види та засоби.

Отже, проаналізоване анкетне опитування серед тренерів дитячоюнацьких шкіл з різним стажем роботи показало, що психологічна підготовка повинна займати важливе місце у спортивній підготовці гімнастів, а також повинна мати ефективний вплив на підготовку гімнастів, від чого буде і залежати їхній виступ на змаганнях. 


\title{
FEATURES OF PSYCHOLOGICAL PREPARATION IN ARTISTIC GYMNASTICS
}

\author{
Kolesnik I. V. \\ Lecturer at the Department of Sports Kinds of Gymnastics \\ National University of Ukraine on Physical Education and Sport \\ Fizkultury str., 1, Kyiv, Ukraine \\ orcid.org/0000-0002-0653-907X \\ irynarosev@ukr.net
}

Key words: types of training, psychology of sports, educational and training process, gymnasts, competition.
The article presents the issues of psychological training in the educational and training process of gymnasts. Also, the results of theoretical research on the study of the peculiarities of psychological training in sports are presented. It is proved that insufficient psychological training can lead to unstable performance in competitions and a failed approach with a poor psychological attitude of the athlete. It should be noted that in gymnastics begin to engage in young gymnasts with an unformed character and not having the stability of moral and volitional qualities.

Therefore, insufficient attention to psychological training is observed at school age, when the child comes to play sports, coaches believe that the most important thing is the development of physical qualities (speed, endurance, strength, flexibility), and the use of special techniques to develop self-confidence in training and before competitions may take a back seat. Also, it should be noted that psychological training is most often used to define a wide range of actions of coaches, athletes and managers, aimed at the formation and development of mental processes and personality traits of athletes and are necessary for successful training and competition. Note also that the direction of psychological training involves the development of motives, will, feelings, abilities, character, temperament and other psychological qualities, as well as forms a specialized perception and dynamics of pre-start states, mental stability, reliability of the athlete.

The article pays special attention to the study of the essence of psychological training of athletes, its types and means are considered.

Thus, the analyzed questionnaire among coaches of children's and youth schools with different work experience showed that psychological training should play an important role in sports training of gymnasts, and should have an effective impact on the training of gymnasts, which will depend on their performance in competitions.
Постановка проблеми. Проблема психологічної підготовки гімнастів набуває все більшої значущості, адже вона відіграє особливу роль у системі тренувань гімнастів і є невід'ємною частиною в підготовці спортсмена [2]. Стати хорошим гімнастом у наш час можна тільки за повного і всебічного використання будь-яких фізичних і психічних можливостей людини [3]. Тому такий вид підготовки включає в себе комплекс засобів і методів, який направлений на успішний виступ на змаганнях різного рівня. Як зазначає практика, часто на змаганнях перемагає той, хто краще психологічно підготовлений, про що і свідчать результати збірних країн на останніх Олімпійських Іграх у Токіо [2; 3].

Недостатня психологічна підготовка може призводити до нестабільного виступу на змаган- нях та невдалого підходу в разі поганого психологічного налаштування спортсмена. Тому тема щодо особливостей психологічної підготовки гімнастів досить актуальна і потребує подальшого вивчення.

Мета та методи дослідження. Мета дослідження - визначити основні особливості психологічної підготовки в спортивній гімнастиці.

Методи дослідження - аналіз науково-методичної літератури, досвід практики, анкетування, системний аналіз.

Аналіз останніх досліджень та публікацій. Багато дослідників [2; 4; 6; 7] вважають, що психологічній підготовці спортсменів потрібно приділяти особливу увагу у зв'язку зі зростанням кількості спортсменів з відносно високим рівнем технічної, фізичної, тактико-теоретичної тощо 
видами підготовки, а також $з$ посиленням конкуренції на змаганнях.

Отже, як зазначають провідні науковці $[1 ; 2 ; 3]$, психологічну підготовку потрібно планувати в тижневому циклі тренувань так само, як і фізичну, спеціальну і технічну підготовку. Адже саме цей вид підготовки має забезпечити вміння гімнастів керувати своїм функціональним станом під дією різних негативних чинників внутрішнього та зовнішнього середовища [2; 5].

Термін «психологічна підготовка» найчастіше використовується для означення широкого кола дій тренерів, спортсменів та менеджерів, що спрямовані на формування і розвиток психічних процесів та якостей особистості спортсменів іє необхідними для успішної тренувальної діяльності та виступів на змаганнях [6].

Отже, із психологією спорту пов'язана низка питань, які напряму пов'язані 3 організацією навчально-тренувального процесу та підготовкою до змагань. Психологічна підготовка спортсменів спрямована на формування особистості спортсмена, виховання вольових якостей, розвиток спортивного інтелекту [8], а також для досягнення успіху в технічній, фізичні та тактичній підготовці спортсменів. У спортивній гімнастиці починають займатися юні гімнасти ще 3 несформованим характером, не маючи стійкості морально-вольових якостей. Рухові можливості гімнастів досить великі, а ось особистісні якості до їх прояву недостатні [2; 3].

Отже, недостатня увага до психологічної підготовки спостерігається ще в шкільному віці, коли дитина приходить займатися спортом, а тренери вважають, що найголовніше - це розвиток фізичних якостей (швидкості, витривалості, сили, гнучкості тощо), а використання спеціальних прийомів щодо розвитку впевненості у своїх силах на тренуваннях та перед змаганнями може відійти на другий план. Це хибна думка, тому що наполегливе прагнення до самого кінця боротися за досягнення мети (нерідко за перемогу), розвиток сили волі, високій рівень стійкості проти негативних зовнішніх і внутрішніх впливів, здатність довільно володіти своїми діями, думками, відчуттями, поведінкою в цілому або, наприклад, самоволодіння, є обов'язковою умовою для занять та перемоги у спорті $[1 ; 2 ; 3]$.

Як зазначає І.П. Волкова, психологічна підготовка - це один 3 аспектів використання наукових досягнень психології, реалізації їі засобів та методів з метою підвищення ефективності спортивної діяльності [4].

Також П.А. Рудик вважає, що психологічна підготовка - це формування, розвиток і вдосконалення властивостей психіки, що потрібні для успішної діяльності спортсменів та команд [8].
М. Осадець зазначає, що напрям психологічної підготовки передбачає розвиток мотивів, волі, почуттів, здібностей, характеру, темпераменту й інших психологічних якостей, а також формує спеціалізоване сприймання і динаміку передстартових станів, психічної стійкості, надійності спортсмена [6].

Також процес підготовки гімнастів вимагає знання про індивідуально-психологічні особливості нервової системи кожного зі спортсменів, починаючи ще 3 початкового етапу навчання. Наприклад, характерною для темпераменту особи є показова амплітуда коливань (від мінімальної до максимальної) темпу діяльності. В одних спортсменів ці переходи здійснюються легко i невимушено, а в інших - 3 великою напругою і частими зривами [7; 8]. Як зазначають провідні науковці, від темпераменту залежить, наскільки швидко людина включається в роботу і з якою швидкістю знижується темп їі діяльності. Інакше кажучи, в руховій дії темперамент виражається в силі, швидкості, ритмі й темпі всіх психомоторних проявів людини $[1 ; 3]$.

На думку Л.П. Сергієнка [9], психологічна підготовка спортсмена - це формування й удосконалення суттєвих для спорту властивостей особистості, а психологічна підготовка спортсменів до змагань - комплекс заходів, спрямованих на оптимізацію психічного стану спортсмена перед стартом в умовах тренувань $[8 ; 9]$.

Розрізняють загальну і спеціальну психологічну підготовку. Загальна психологічна підготовка характеризується спрямованістю на формування і розвиток універсальних (різнобічних, придатних для багатьох цілей) властивостей особистості та психічних якостей, які є головними в спорті та цінуються в багатьох інших видах людської діяльності. До даного виду підготовки належать: підготовка до тривалого тренувального процесу, соціально-психологічна та вольова підготовка, змагальний досвід, здатність до самовиховання $[3 ; 6]$.

Спеціальна психологічна підготовка характеризується спрямованістю на формування і розвиток психічних якостей і властивостей особистості, які сприяють успіху в особливих, конкретних умовах спортивної діяльності. Вона включає підготовку до змагання, етапу тренування чи зустрічі із суперником, ситуативне управління станом [6].

Результати дослідження та їх обговорення. У результаті визначення особливостей психологічної підготовки гімнастів у процесі спортивного тренування було проведено анкетне опитування серед 14-ти респондентів (тренери 3 різним досвідом роботи зі спортивної гімнастики м. Житомир, м. Суми та м. Києва). При 
цьому використовувалась анкета закритого типу, яка включала в себе 7 запитань. Тренерам пропонувалося прочитати кожне питання і виділити один варіант 3 відповідей, який найбільш імпонує власній думці кожного респондента.

Результати проведеного серед тренерів анкетного опитування (таблиця 1) свідчать про те, що $50 \%$ опитаних тренерів уважають, що психологічна підготовка повинна відігравати важливу роль і взаємодіяти напряму з іншими видами підготовки, 56\% респондентів уважають, що натепер психологічна підготовка віднесена на 3-тю сходинку серед фізичної та технічних видів підготовки, про що зазначено в таблиці 1.
У третьому питанні нашого опитувальника на запитання «Чи використовуєте ви види та засоби психологічної підготовки в навчально-тренувальному процесі гімнастів?» 21,4\% відповіли «Так», 42,9\% - «Ні», 35,7\% - «Частково».

На запитання «Чи завжди у Вас знайдеться можливість для довірливого спілкування у вигляді бесід, переконливих прикладів, справедливо обгрунтованих наказів, аргументованого прогнозування успіху для спортсменів?» 14,3\% респондентів відповіли «Так», 28,6\% - «Ні», 35,7\% - «Не завжди», 21,4\% - «Не бачу в цьому потреби».

Результат відповіді на п'яте запитання нашого опитувальника «Чи впливають відносини в сім’і

\section{Оцінка психологічної підготовки гімнастів $(\mathrm{n}=14)$}

\begin{tabular}{|c|c|c|}
\hline $\begin{array}{l}\text { № } \\
\text { ПI/II }\end{array}$ & Запитання та варіанти відповідей & $\begin{array}{l}\text { Результати } \\
\text { відповіді на } \\
\text { запитання } \\
(\%) \\
\end{array}$ \\
\hline \multirow[t]{4}{*}{1.} & $\begin{array}{l}\text { Яку роль, на Вашу думку, виконує психологічна підготовка в спортивній підготовці гімна- } \\
\text { стиці? }\end{array}$ & \\
\hline & $\begin{array}{l}\text { a) важливу, оскільки вона забезпечує досягнення стабільності та високого результату і } \\
\text { взаємодіє з іншими видами підготовки }\end{array}$ & $50 \%$ \\
\hline & б) другорядну роль & $28,6 \%$ \\
\hline & $\begin{array}{l}\text { в) не суттєву, результат досягнень залежить від } \\
\text { фізичної та технічної видів підготовки }\end{array}$ & $21,4 \%$ \\
\hline \multirow[t]{4}{*}{2.} & $\begin{array}{l}\text { На яке місце за рейтингом можна віднести фізичну, технічну та психологічну підготовку у } \\
\text { підготовці гімнастів }\end{array}$ & \\
\hline & a) 1 & $27 \%$ \\
\hline & б) 2 & $17 \%$ \\
\hline & B) 3 & $56 \%$ \\
\hline \multirow[t]{4}{*}{3.} & $\begin{array}{l}\text { Чи використовуєте ви види та засоби психологічної підготовки в навчально- тренувально- } \\
\text { му процесі гімнастів? }\end{array}$ & \\
\hline & a) Так & $21,4 \%$ \\
\hline & б) $\mathrm{Hi}$ & $42,9 \%$ \\
\hline & в) Частково & $35,7 \%$ \\
\hline \multirow[t]{5}{*}{4.} & $\begin{array}{l}\text { Чи завжди у Вас знайдеться можливість для довірливого спілкування у вигляді бесід, пере- } \\
\text { конливих прикладів, справедливо обгрунтованих наказів, аргументованого прогнозування } \\
\text { успіху для спортсменів? }\end{array}$ & \\
\hline & e & $14,3 \%$ \\
\hline & б) $\mathrm{Hi}$ & $28,6 \%$ \\
\hline & в) Не завжди & $35,7 \%$ \\
\hline & г) Не бачу в цьому потреби & $21,4 \%$ \\
\hline \multirow[t]{4}{*}{5.} & Чи впливають відносини в сім’ї на психоемоційний стан спортсмена? & \\
\hline & a) Так & $71,4 \%$ \\
\hline & б) $\mathrm{Hi}$ & $7,2 \%$ \\
\hline & в) Не завжди & $21,4 \%$ \\
\hline \multirow[t]{4}{*}{6.} & $\begin{array}{l}\text { Як ви вважаєте: на що повинна бути направлена робота психологічної підготовки на почат- } \\
\text { ковому етапі навчання? }\end{array}$ & \\
\hline & а) на вироблення стійкої мотивації до занять спортом & $57,1 \%$ \\
\hline & б) на формування позитивного соціально-психологічного клімату в спортивній групі & $14,3 \%$ \\
\hline & в) на розвиток стресостійкості до поразок та невдач на тренуваннях і змаганнях & $28,6 \%$ \\
\hline \multirow[t]{5}{*}{7.} & $\begin{array}{l}\text { Який, на Ваш погляд, формат заняття проведення психологічної підготовки найбільш } \\
\text { ефективний? }\end{array}$ & \\
\hline & а) груповий & $21,4 \%$ \\
\hline & б) індивідуальний & $57,1 \%$ \\
\hline & В) командний & $7,1 \%$ \\
\hline & г) залежить від ситуації & $14,4 \%$ \\
\hline
\end{tabular}


на психоемоційний стан спортсмена?» відображений на Рис. 1.

71,4\% відповіли, що «Так», 21,4\% вважають, що «в залежності від ситуації».

Шосте питання спрямовано на те, щоб дізнатися, на що повинна бути направлена психологічна підготовка на початковому етапі навчання.

$57,1 \%$ опитаних вважають, що на початковому етапі головне - це вироблення стійкої мотивації до занять спортом;

$14,3 \%$ опитаних вважають, що це формування позитивного соціально-психологічного клімату в спортивній групі;

$28,6 \%$ опитаних вважають, що розвиток стресостійкості до поразок та невдач на тренуваннях і змаганнях.

Відповіді на запитання щодо визначення ефективності формату проведення занять «Який, на Ваш погляд, формат заняття проведення психологічної підготовки найбільш ефективний?» відображено на рис. 3.

$57,1 \%$ респондентів віддали перевагу «індивідуальній» формі;

$21,3 \%$ - груповій;
14,4\% - залежно від ситуації;

$7,1 \%$ - командній.

Отже, в результаті проведення нашого дослідження слід зазначити, що успішний виступ на змаганнях залежить не тільки від високого рівня фізичної, технічної і тактичної підготовленості спортсмена, а й від його психологічної готовності [2]. У навчально-тренувальних групах зі спортивної гімнастики потрібно робити акцент на розвиток спортивного інтелекту, здатність до саморегуляції, формування вольових рис характеру, покращення взаємодії в спортивній групі $[2 ; 3]$.

Висновки. Аналіз наукових даних свідчить про те, що психологічна підготовка відіграє важливу роль у системі підготовки гімнастів, включаючи комплекс засобів і методів, які направлені на успішний виступ на змаганнях різного рівня і забезпечують досягнення стабільності та високого результату у взаємодії з іншими видами підготовки.

У результаті дослідження було визначено основні особливості психологічної підготовки гімнастів 3 боку тренерів, починаючи 3 почат-

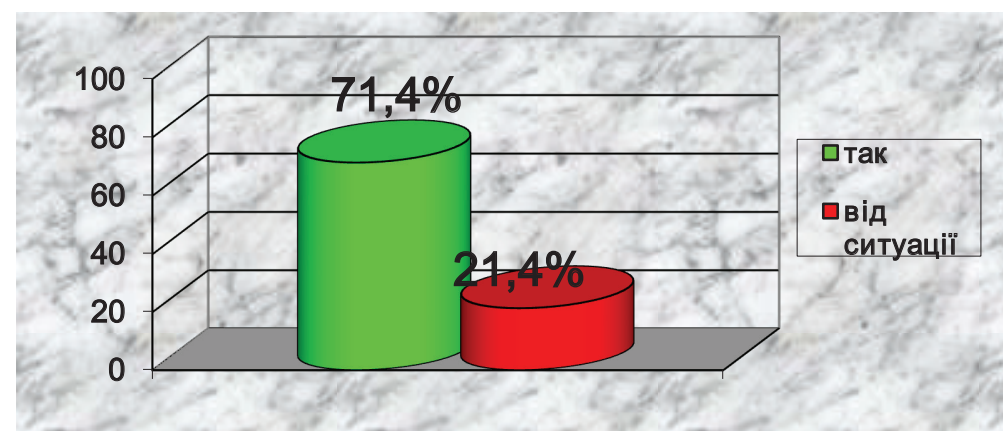

Рис. 1. Вплив відносин у сім'ї спортсмена

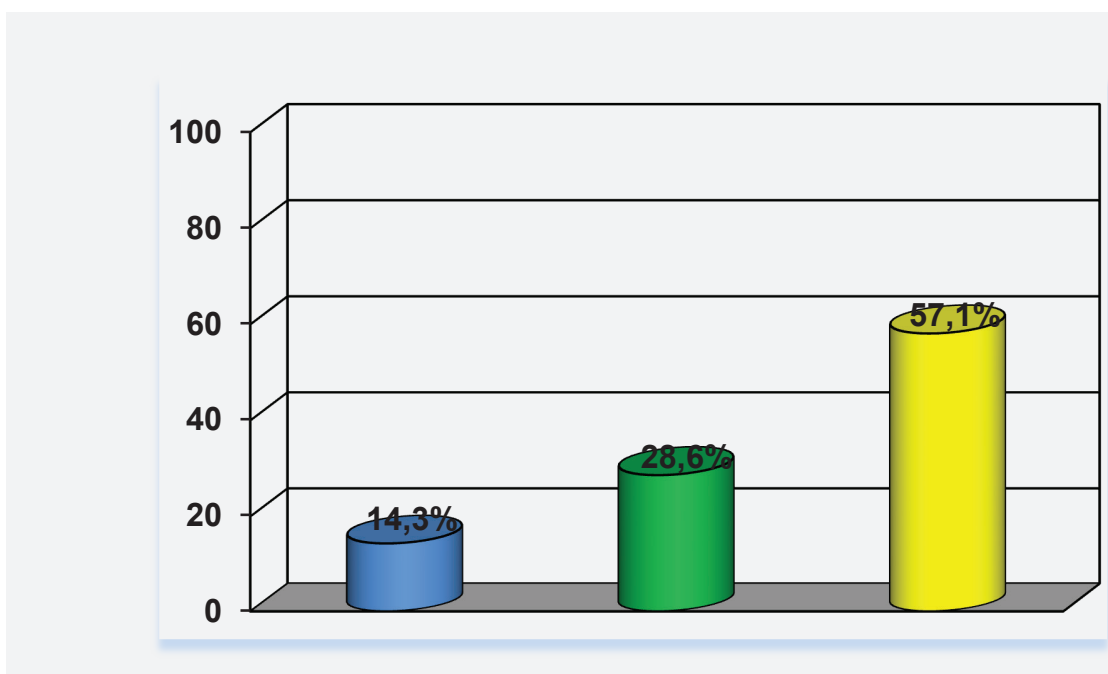

Рис. 2. Направленість психологічної підготовки 


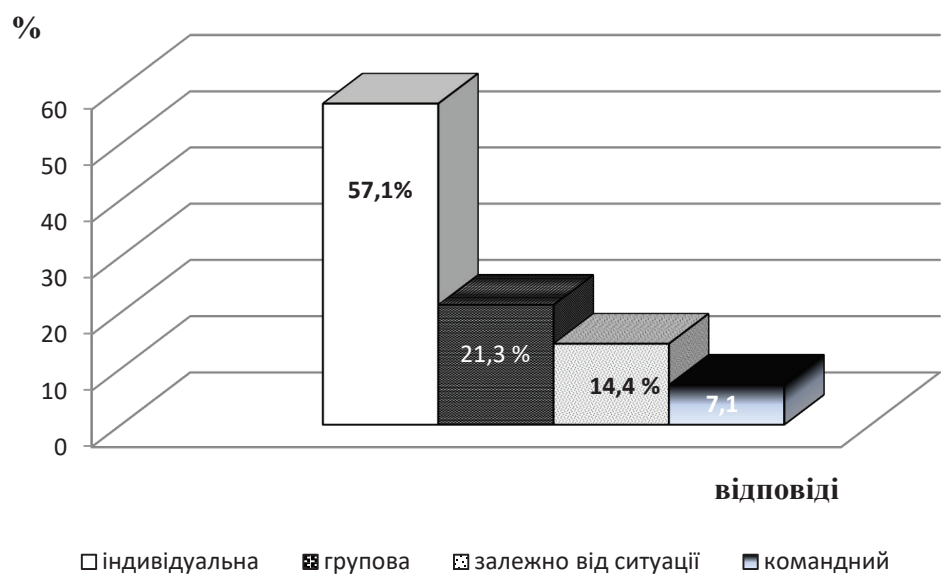

Рис. 3. Формат занять проведення психологічної підготовки

кового етапу навчання. Слід зазначити, що 50\% респондентів уважають, що психологічна підготовка займає важливе місце в навчально-тренувальному процесі, оскільки вона забезпечує досягнення стабільності та високого результату і взаємодіє 3 іншими видами підготовки, але також 56\% опитаних вважають, що поки психологічна підготовка знаходиться на 3-му місці в рейтингу серед фізичної та технічної видів підготовки. Також 57,1\% респондентів вважає, що психологічна підготовка на початковому етапі навчання повинна бути направлена на вироблення стійкої мотивації до занять спортом, 14,3\% - на формування позитивного соціально-психологічного клімату в спортивній групі, 28,6\% - на розвиток стресостійкості до поразок і невдач на тренуваннях та змаганнях.

Отже, питання щодо психологічної підготовки в тренувальному процесі є темою досить актуальною, яку потрібно досліджувати та удосконалювати під час підготовки гімнастів.

\section{ЛІТЕРАТУРА}

1. Воронова В.І. Психологія спорту : навч. посіб. 2-ге вид. Київ : НУФВСУ, вид-во Олімп. л-ра, 2019. 272 c.

2. Гавердовский Ю.К., Смолевський В.М. Теория и методика спортивной гимнастики : учебник. Москва : Советский спорт, 2014. 232 с.

3. Ильин Е.П. Психология спорта : учебник. Санкт-Петербург : Питер, 2012. 352 с.

4. Волкова И.П. Практикум по спортивной психологии. Санкт-Петербург : Питер, 2002. 288 с.

5. Клименко В.В. Психологія спорту : навч. посіб. для студ. вищ. навч. закл. Київ : МАУП, 2006. C. $423-424$.

6. Осадець М. Психологічна підготовка особистості в спорті. Нова педагогічна думка. 2014 . № 4 (80). C. $155-157$.

7. Родионов А.В. Влияние психологических факторов на спортивный результат. Физкультура и сnорт. 2006. $112 \mathrm{c}$.

8. Рудик П.А. Психологические аспекты спортивной деятельности. Психология и современный спорт. 2010. $217 \mathrm{c}$.

9. Сергієнко Л.П. Практикум з психології спорту. Харків : ОВС, 2007. 271 с.

\section{REFERENCES}

1. Voronova V.I. (2019) Psykhologhija sportu [Psychology of sport]. Kiev: NUFVSU, vyd-vo Olimp. 1-ra,. pp. 272.

2. Gaverdovskiy Yu.K., Smolevs'kiy V.M. (2014) Teoriya i metodika sportivnoy gimnastiki: [Theory and methodology of artistic gymnastics]. Moskva: Sovetskiy sport. (in Russian).

3. Il'in E.P. (2012) Psikhologiya sporta [Psychology of sport].Sankt-Peterburg: Piter. (in Russian).

4. I. P. Volkova (2002) Praktikum po sportivnoy psikhologii [practicum on Sports Psychology]. Piter. (in Russian).

5. Klymenko V. V. (2006) Psykhologhija sportu [Psychology of sport]. Kiev: MAUP, P. 423-424.

6. Osadecj M. (2014) Psykhologhichna pidghotovka osobystosti v sporti. [Psychological training of personality in sports]. Nova pedaghoghichna dumka. vol. 4. 80. P. 155-157. 
7. Rodionov A. V. (2006) Vliyanie psikhologicheskikh faktorov na sportivnyy rezul'tat. [The influence of psychological factors on sports performance]. Fizkul'tura i sport. Pp. 112.

8. Rudik P. A. (2010.) Psikhologicheskie aspekty sportivnoy deyatel'nosti [Psychological aspects of sports activity] Psikhologiya i sovremennyy sport. Pp. 217.

9. Serghijenko L. P. (2007) Praktykum z psykhologhiji sportu. [practicum on sports psychology]. Kharkiv : OVS. Pp. 271. 